\title{
The Improvement of Capital Budgeting at the State Level in the USA
}

\author{
Natalia Ermasova ${ }^{1}$ \\ ${ }^{1}$ College of Business and Public Administration, Governors State University, University Park, Illinois, USA \\ Correspondence: Natalia Ermasova, C3340, 1 University Parkway, College of Business and Public Administration, \\ Governors State University, University Park, Illinois, USA, 60484. Tel: 1-708-534-4978. E-mail: \\ nermasova@govst.edu
}

Received: July 23, $2013 \quad$ Accepted: August 5, $2013 \quad$ Online Published: September 29, 2013
doi:10.5539/par.v2n2p92
URL: http://dx.doi.org/10.5539/par.v2n2p92

\begin{abstract}
This study examines capital budgeting processes at the state level in the USA. This research examines the effects of economic decline on changes in capital budgeting practices. The secondary sources of information were analyzed, including data from state web-sites, Bureau of Economic Analysis (BEA) data, and National Association of State Budget Officers (NASBO) reports. Based on these analytical materials, the author choose capital budgeting practices of following states as the examples of the successful use of analytics, data, and performance information: California, Delaware, Georgia, Indiana, Maryland, Massachusetts, Montana, New York, Oregon, and Vermont. The result of this research will improve the knowledge about best practice in capital planning and budgeting and, finally, will contribute to greater efficiency in capital spending within state and without states. This research will expand knowledge of successful use of analytics, data, and performance information in capital budgeting processes across boundaries for practicing planners, developers, budget analytics, debt managers, and policy makers in the areas of regional collaboration, capital planning, and capital budgeting. This study expands knowledge of capital budgeting "best practices" for practicing planners, developers, budget analytics, debt managers, and policy makers in the areas of capital planning, financing, and budgeting.
\end{abstract}

Keywords: USA, capital budgeting, state government, public infrastructure, capital financing

\section{Introduction}

The availability and quality of services provided by public infrastructure - water, sewers, solid waste facilities, public transit and transportation systems, communication systems, cultural and recreational facilities - are critical factors in improving economic growth. According to the Department of the Treasury and the Council of Economic Advisers (2010, p.1), "well designed infrastructure investments can raise economic growth, productivity, and land values, while also providing significant positive spillovers to areas such as economic development, energy efficiency, public health and manufacturing." The Department of the Treasury and the Council of Economic Advisers (2010, p.6) emphasized that "public infrastructure is an essential part of the U.S. economy. Businesses depend on a well-functioning infrastructure system to obtain their supplies, manage their inventories, and deliver their goods and services to market. A modern transportation infrastructure network is necessary for our economy to function, and is a prerequisite for future growth." Srithongrung $(2008$, p.91) pointed out that "capital management processes based on systematic and strategic practices should result in an effective infrastructure system that can attract private investment and new residents."

This paper examines states' capital budgeting processes through which planning, financing, and coordination process are shaped, either by the initial regional context and economic conditions. This research advances theory with a more sophisticated analysis of complex interactions among these factors, and examines the effects of economic decline on changes in capital budgeting practices. Given the importance of capital expenditures, the condition of capital infrastructure at the state level and the scope of capital financing exploration of capital budgeting at the state level are significant. This study provides insights that will be of interest to both public finance researchers and to policy makers. The findings will allow state officials to compare the various techniques and methods of capital budget preparation.

According to Premchand (1993, p. 54), "greater attention was paid to dealing with uncertainty and to formulating contingent management strategies if the situation improved or deteriorated." The effect of recessions on state fiscal 
capacity over time has been increasingly negative, indicating that in the modern era, state revenue systems remain vulnerable and less flexible under fiscal stress (Mikesell, 2007).

The broad amount of different theoretical and empirical works on capital budgeting during economic decline can be divided into the following groups: (1) research that suggests that effective capital budget process and planning is incremental; (2) research that demonstrates the efficiency of a multiyear budget process and also advocates for countercyclical fiscal policies; (3) studies that propose using an emergent budget process, for example, cutback management - during the economic downturn; (4) studies that recommend that the optimal strategy is the midpoint on the emergent-to-planned strategy continuum; and (5) research that proposes economic decline as the trigger for innovations.

There is a group of scholars who suggest that "budgeting is incremental, not comprehensive. An agency's budgets based on last year's budget with special attention given to a narrow range of increases or decreases" (Wildavsky, 1964, p.15). Agencies act as advocates, protecting their budget base and requesting small ("incremental") increases from the previous year (Lindblom, 1959; Davis, Dempster, and Wildavsky, 1966; Wildavsky, Caiden, 2000).

LeLoup (2002, p.13) defined what an emerging new paradigm of budgeting might look like in terms of the nature and scope of budgeting: (1) a balance between macro- and micro-level, (2) less comprehensive but broad multiyear budgeting. But in his opinion, these changes in budgeting can occur only during positive economic growth. In positive-budgeting, strong-growth environments, the public needed little reassurance of the value of public spending. In negative-budgeting, weak or slow-growth (sometimes called slowth) environments, the nexus between tax payments for public revenues and budget benefits for public expenditures must be reestablished (Hyde, 2002, pp.458-459).

This direction of theories is similar to Keynes's countercyclical fiscal policies, that is, policies that acted against the tide of the business cycle: deficit spending when a nation's economy suffers from recession or when recovery is long-delayed and unemployment is persistently high - and the suppression of inflation in boom times by either increasing taxes or cutting back on government outlays. Keynes (1924) argued that governments should solve problems in the short run rather than waiting for market forces to do it in the long run, because, in the long run, we are all dead. Hou (2006) called for a countercyclical policy approach in which budgeting for stability involves saving for the downturns in the economy's business cycles. Simply put, he suggests saving during times of economic boom to meet expenditures during economic recessions. Such a countercyclical policy approach involves taking a multiyear approach to budgeting, rather than an annual approach. An annual budgeting approach's strength lies in its spending controls and its management of day-to-day operations, but it is not adequate for facing economic distress. Hou (2006, p.732) pointed out that "politically, the [annual] budget was a governance tool to promote democracy and curb corruption; managerially, it was intended to coordinate the legislative and executive branches; and technically, it aimed to improve administrative efficiency." The best that the annual budgets can do in terms of preparing for future economic downturns is to accumulate annual surpluses. However, annual budgets are not sufficiently equipped for dealing with the political and legal demands associated with running surpluses. Hence, surpluses generally tend to be small. Hou (2006, p.732) argued that "when surpluses are not sufficient, account books cannot be balanced and deficits result... With only one year's span, the annual budgeting cycle cannot guarantee a balanced budget and makes it more difficult for state and local governments to ensure balanced budgets in the long run or maintain stable spending for necessary service levels during lean years." Boex and McNab (2000, p.110) also advocated for multi-year techniques (medium-term financial plans) that "can offer significant benefits, such as forewarning potential fiscal imbalances in future years and enhancing aggregate budget discipline, and to evolve the multi-year budget framework into a more integrated approach over time." They highlighted several potential benefits of a multi-year budget approach: (1) placement of a more explicit and consistent statement of policy goals and priorities; (2) a signal whether current policies and their future implications are at odds with this fiscal strategy; (3) providing continuity to the budget process by placing the annual budget discussion in the context of the government's medium-term fiscal strategy and policy priorities; (4) improving efficiency in the allocation of public resources by enhancing transparency and accountability in the budget process, and (5) providing a mechanism for the systematic review of expenditure priorities and commitments; (6) providing the way for cooperation between various government agencies (Boex, Martinez, \& McNab, 2000, p.92).

Kovner and Lusk (2010) proposed a sustainability budgeting model that suggests a way to combine budgeting and the planning process to achieve inflows relative to outflows that ensure long-term budget balance and thus, a sustainable fiscal status. This model calibrates the revenue inflows and outflows for various time horizons using present value concepts. The model calls for looking at three scenarios for each project or focus of funding: best case (inflows/revenues high and outflows/costs relatively low), average case (revenues and costs fall somewhere 
in between best case and worst case), and worst-case scenarios (highest relative outflows/costs and lowest relative inflows). The expected value is calculated by estimating the likelihood of the best case, average case, and worst-case scenarios taken together. The expected value projection for a project or funding focus can then be compared to a defined breakeven range. This model that is related to variability and balancing inflows/revenues and outflows/costs is analogous to planning for budgetary responses in the event of budget shortfalls brought on by economic downturns. Klase (2011, p.205) suggested that this model "provides an interesting and conceptually useful approach for making choices between projects or funding areas in planning an operating budget to keep it balanced in the long-term." The Pew Center on the States (2009) has identified four important components of establishing an effective long-term budget: (1) Estimate revenues and expenditures into the future; (2) Consider the long-term impact of tax and expenditure decisions; (3) Manage long-term liabilities; (4) Maintain a reasonable level of debt.

On the other hand, Boex, Martinez-Vazquez, and McNab (2000, pp.91-92) highlighted several of the potential drawbacks that are associated with a multi-year budget approach: "(1) excessive reliance on the forward estimates in the annual budget formulation process could result in inflexibility and inertia in fiscal policies; (2) overly optimistic multi-year projections could be used as a justification for otherwise unjustifiable public spending programs; (3) a full-blown, multi-year budget approach may be a complex and administratively costly tool which may divert attention and resources from the more fundamental task of developing adequate annual budgets."

A third group of authors suggests using an emergent strategy. The primary example of emergent strategy is cutback management. From its earliest origins in the 1970s, cutback management theory has focused on how governments respond to situations of decline and what tactics the governments use to manage cutbacks. The cutback management becomes more than a management reaction to adverse economic conditions. Research concerning cutback management largely draws upon Charles H. Levine's article "Organizational Decline and Cutback Management" (1978), which indicates than more than a half-century of "positive budgeting" was over. "Negative budgeting" seemed destined to dominate budget thinking. Cutback management was not intended to be a budgetary system; rather, it is a process. Its objective is to fuse political-economic realities with management strategies that will reestablish in the public's mind the value of public-sector programs and services. The cutback budgeting initiated in many states during the recession of 1981-83 disrupted budgetary incrementalism and its norms of conflict-avoidance (Behn, 1985). Controlling expenditures again became the dominant orientation of central budget offices. Levin (1980) and Miller (1983) wrote about the variation of state responses to recessions that was used across states, such as travel restrictions, space utilization, hiring freezes, across-the-board cuts, and use of bonds, during the recession in the early 1980s. Levine, Rubin, and Wolohojian (1981) proposed the administrative response model of cutback management, which shows that cut-back management begins with broad, across-the-board cuts and then moves on to targeted program eliminations and major budget reductions as the severity of revenue restrictions increases. Research after 2000 and in particular after 2007 has begun to provide some evidence of state responses to recessions and their correspondence to cutback management frameworks. Scorscone and Plerhoples (2010) noted that during the current recession, states used budget cuts and restructuring over tax-raising efforts to a much greater extent than in previous recessions. Bowling and Burke (2006) found few differences in the cutback strategies used by states between the 1984 and 2004 time periods, with general cutbacks strategies, such as hiring freezes, pay freezes, layoffs, productivity improvements, being used at the same rate and with the same scope; however, states with tax limits utilized a broader and deeper set of cutback strategies (Scorcone and Plerhoples, 2010). Thurmaier and Gosling (2008, p. 121) wrote that candidates increasingly run on platforms to cut government expenditures and taxes, preferring to let markets have a larger role in shaping society. Dougherty and Klase (2009) examined cutback strategies in eight mid-Atlantic and eastern states during the 2001 recession and found support for the administrative response model of cutback management that was advocated by Levine, Rubin, and Wolohojian (1981). Finally, Rubin and Willoughby (2009) proved that the cutback strategies chosen depend on economic circumstances, as might be expected according to the fiscal pressure and administrative response models of cutback management.

There are different points of view on changes in budgeting during economic decline. According to Premchhand (2006, p.27), "the nature and dimensions of the fiscal stress was such that it became abundantly clear that the traditional methods of nip and tuck, or a cut here or there in the sectoral allocations, would not serve the purpose." This cutback management had to be combined with deficit reduction packages. Titus, Covin and Slevin (2011), Mintzberg's (1994) proposed that effective strategy formation process should include both orientations: emergent strategy orientation and planned strategy orientation. Titus, Covin and Slevin (2011, p.451) suggested "neither purely emergent nor purely planned strategy should be regarded as inherently desirable" in the private sector. This emergent-to-planned strategy continuum can be used in the public sector, particularly, in the capital budgeting 
process. Pure cutback management can lead to $a d$ hoc and non-purposeful strategies. Likewise, a strong planning orientation may contribute to a false sense of control (Mintzberg, 1990). Budget analytics should focus not only on transaction processing or control functions, but also on capital budget and policy development. Willoughby (2002, p.112) highlighted that budget analysts "will exhibit a broader range of roles in the budget process than their counterparts in control oriented budget offices." According to Premchand (1993, p.57), "in a crisis, the first task is to determine the nature of the crisis, the factors contributing to it, whether it is short term or medium term." It is important to analyze whether it is a general problem afflicting the whole economy or only the state. Premchand (1993, p.57) provided a good analogy of strategic management during fiscal stress with "the role of an aircraft pilot who has to determine whether the turbulence is short and temporary or likely to be prolonged. If it is the latter, a decision on whether any change in the flying altitude is necessary would prove useful."

\section{Analysis of the Practice of Capital Budgeting at the State Level before Great Recession}

In the early 1920s, some cities began a comprehensive approach to capital planning with the development of local Master Plans, and by the end of the decade, capital budgets emerged to link the planning process to realistic assessments of the community's willingness to pay for what was being planned (President's Clinton Commission, 1999). This process continued into the 1930s. According to LeLoup (2008, p.76), "The American states have often been a source of policy innovation and experimentation that later affects national policy. The differences between budgeting at the state and national levels have increased since 1921. The use of the federal budget as a tool of fiscal policy in the 1930s created a permanent gulf between state and national budgets." The biggest difference between capital budgeting at the state and national levels is the separation of the capital budget from the operating budget in most states, and the lack of a separate capital budget at the federal level.

The approach to capital budgets varies among state governments. The States differ substantially in how they define capital, the degree to which capital is separate in the governor's proposed budget and in the legislature's budget, and the means by which they finance capital expenditures.

Bozeman (1984) identifies four factors that led to the development of public sector capital budgets:

1) The emergence of official planning commissions in the 1920s resulted in Master Plans for the physical development of communities.

2) In the field of public administration, increased attention was paid to budgeting in general and the improvement of administrative practices and their policy implications.

3) The Great Depression caused communities to learn that massive public works projects could lead to fiscal crises and bankruptcies if the limits to resources were not recognized.

4) World War II caused communities to plan for the return of soldiers and the concomitant need for new roads, schools, water and sewer lines, and other infrastructure.

By the late 1940s, capital planning and capital budgets were in place in many communities and some states. Since the early 1960s, capital budgeting has become more widespread among the states. Not surprisingly, states differ in both their capital budgeting and capital financing practices. Studies of state budgeting practices, such as Hillhouse and Howard (1963); the survey by the Council of State Governments (1969); Hush and Peroff (1986) and the National Association of State Budget Officers (1992), documented this trend.

In the early 1960s, Hillhouse and Howard (1963) conducted a comprehensive study of U.S. state capital budgeting practices. They found that budgeting practices for capital expenditures varied widely across states. Some state budgets did not distinguish between capital and operating expenditures, but instead aggregated funds by function, such as education or health care. Other states separated capital from operating expenditures in their budgets and held distinct sets of hearings on the two. Some states even developed multi-year capital plans to forecast future capital and financial needs, although none charged capital depreciation to their budgets.

Hillhouse and Howard (1963) grouped states into four categories based on their budgeting rules for non-highway expenditures: (1) states that make no budgetary distinction between capital and operating expenditures; (2) states that have separate budgets for capital and operating expenses, but do not engage in capital expenditure planning over horizons longer than the operating budget cycle; (3) states that have separate capital and operating budgets as well as "capital programs," schedules of physical projects that extend beyond the operating budget horizon; and (4) states that prepare separate capital and operating budgets, and also prepare multi-year capital budgets that extend beyond the operating budget cycle. Multi-year capital budgets differ from capital programs in presenting an integrated physical and financial plan for capital expenditures. Capital programs are thus an intermediate ground between the unified budgets used in some states, and the multi-year capital budgets used in others. Sixteen of the 48 continental states used capital budgets and capital programs in 1962 and an additional 13 states had capital 
budgets, but no capital program. The states with capital budgets were concentrated in the Northeast, the Far West, and the upper Midwest. In 1967, the states east of the Mississippi tended to borrow for capital purchases, while pay-as-you-go (PAYG) restrictions were found most often in the West.

The 1967 President's Commission on Budget Concepts and the 1999 President's Commission to Study Capital Budgeting analyzed the practice of capital budgeting at the state level to determine the feasibility of separate capital budgeting on the federal level. Both Commissions rejected the idea of a separate capital budget for the federal government, but found numerous advantages to a separate capital budget at the state level. Hillhouse and Howard (1963) found that 29 states had separated capital budget. Hush and Peroff (1986) reported that 32 continental states had capital budgets. Hush and Peroff (1986) found that just over half of the states with capital budgets treat major maintenance expenditures as capital spending, while other states require popular referenda to approve new debt issues, and in still others, the legislature is essentially unrestricted in its ability to borrow. Hush and Peroff (1986) highlighted that only three of the 34 states with capital budgets, and six of the 16 without, generally used current revenues to finance capital spending. They also found that the states east of the Mississippi tended to borrow for capital purchases, while pay-as-you-go (PAYG) restrictions were found most often in the West. The National Conference of State Legislatures (1987) analyzed the constitutional limitations on government indebtedness. It found that states with capital budgets display substantial idiosyncratic variations in their definition of capital goods. New purchases are categorized as "capital goods" if their useful life, and, in some cases, purchase price, exceeds some threshold.

In 1986, the U.S. Office of Management and Budget reviewed issues concerning the possible development of a federal capital budget (Godman, 1987). A survey concerning the use by states of capital budgets was conducted as part of this study. The U.S. General Accounting Office (1986) also completed a survey in 1986, in which 37 of the 45 states that responded had capital budgets. A GAO study on Leading Practices in Capital Decision Making (1999) indicated that the integration of the investment decision within an organization's strategic goals is critical to selecting successful capital projects.

The National Association of State Budget Officers (NASBO) conducted capital budgeting surveys in both 1997 and 1999. These studies indicated that many states reported having a distinct capital budget, with the capital and current operations amounts being reported separately either within an overall budget or in separate budgets. Forty-two states had separate budgets for current operating costs and for capital expenditures. These studies indicated some large differences across states. At the top of the scale, Arizona, Minneapolis, Texas, Virginia, and Kansas City demonstrate consistently strong performance in all four elements of capital management. These states are often among the leaders in the quality of their CIP document, in the thoroughness of their project management systems, and in the development of asset management systems. States that were ranked fairly low in capital management in 1997 were shown to be making substantial improvements in their capital planning systems at the time of the 1999 survey.

According to the report Budget Processes in the States (NASBO, 2009), all states but Mississippi and Alabama published a separate capital budget document that forecasted operating expenditures for capital projects. However, the number of years included in the capital plan varied across states. Nevada and Washington forecasted 9 and 10 years, respectively, but 19 states had a forecast horizon of five or fewer years. According to Budget Processes in the States, 14 states project revenue estimates at least four years into the future, but as many as 17 states project only one or zero years beyond the current budget cycle. States also vary greatly in terms of the extent to which they forecast spending, and their capacity to do so.

The analysis of the Political Economy Research Institute (2009) shows that the overall level of capital spending clearly varies according to the size of the state - in 2006, spending ranged from a low of $\$ 441$ million in Vermont to a high of $\$ 41.8$ billion in California (Heintz, Pollin, and Garrett-Peltier, 2009). The Political Economy Research Institute (2009) also provided a comparative analysis on per capita public investment in 2006 for eight categories of infrastructure: education, health, highways, natural resources and recreation, waste management (wastewater and solid waste), water systems, energy, and public transit. Alaska has a high level of per capita public investment, but this is largely due to high investments in roads and energy infrastructure. In 2006, only six states spent more than $\$ 75$ per person on investments in public transportation: New York, the District of Columbia, Washington, New Jersey, Massachusetts, and Illinois. Investments in energy infrastructure also vary widely by state, partly due to the fact that the public-private mix in the provision of infrastructure varies between states.

Research by the National Association Budget Officers (NASBO) (1999), Office of Management and Budget (OMB) (1986), and President Clinton's Commission (1999) found some general tendencies: (1) Most state governments maintain a capital budget that is separate from the operating budget; (2) Most states have long-range 
capital plans, ranging from three to ten years, with five years being the most frequent planning horizon; (3) The states most satisfied with their capital budgeting process use some method of keeping their legislatures regularly informed about capital needs (a separate committee charged with overseeing all or most capital projects and their financing); (4) State governments use different methods to set priorities in deciding on their capital expenditures, using project-by-project, case-by-case, or formal mechanisms, either in statute or by practice, or by setting priorities on a functional basis (i.e., allocating expenditures for higher education, transportation, aiding local governments, or protecting natural resources) or by setting priorities for certain activities, such as health and safety; (5) States often dip into general revenues to pay for capital items, using excise taxes (such as taxes on gasoline), or using grants from the federal government; and (6) Most states have either constitutional or statutory limits (often with referendum requirements) on the amount of debt they may issue.

\section{Analysis of the Practice of Capital Budgeting at the State Level during and after Great Recession}

Economic decline is a reason for the widening gulf between available fiscal resources and needs. It can lead to concern that capital expenditure commitments made during more stable years could no longer be continued. Some states used cut-back management. Montana withdrew some previously approved projects and no new projects were approved. Capital financing was approved only for safety issues during the last legislative session in 2011. Nevada reduced the number of capital projects. Washington started to finance "shovel-ready" projects only. Utah's Governor's Office of Planning and Budget did not approve the building of new facilities for three years.

In response to economic decline, many states explore several directions to minimize or deal with the fiscal stress through improvements in capital budgeting:

(1) Improved budget-making through a special computer database (California, Indiana, Wisconsin, and Virginia).

(2) Recognition of performance links and economic stimulus (California, Delaware, Vermont, Tennessee, and Virginia).

(3) Some states increased the duration of capital budget. In Vermont, the duration of the capital budget shifted from one to two years. Nebraska, in certain instances, extended the timing of capital projects from a two-year period to a three or four-year period.

(4) Greater emphasis on the prioritization and selection process (California, Indiana, Kentucky, Montana, North Carolina, Pennsylvania, Tennessee, and Virginia),

(5) Emphasis on improved governance through greater fiscal transparency and an enhanced framework of financial and program accountability as well as collaborative initiatives and teamwork (observed in Indiana, Nebraska, and Washington),

(6) Improved coordination with the operating budget (observed in Indiana, Montana, Nevada, Tennessee, Pennsylvania, Washington, and Wisconsin).

(7) Additional emphasis on the planning and execution of preventive maintenance (observed in Indiana, Massachusetts, Nebraska, South Carolina, Tennessee, and Virginia).

According to Ermasova (2013, p.125), "in Montana and New Jersey, maintenance has been moved from the capital budget and into the departments' budgets since the beginning of the Great Recession in 2008. Other states such as Alabama, Indiana, Maryland, Massachusetts, South Dakota, Utah, and New York have developed a system to rate maintenance projects as part of the effort to preserve facilities." According to Indiana's 2012 Capital Budget Instructions:

"Successful capital planning and budgeting requires long-term planning, looking well beyond the current biennium to determine the investments that need to be made to maintain, and possibly extend, the useful life of the asset, and to ensure that capital investments are closely aligned with agency and program goals. With proper long-term planning and timely PM, additional large and/or unexpected capital investments should be minimized."

States have modified their capital budgeting processes since the last NASBO reports "Capital budgeting in the states" (1999) and "Budget processes in the states" (2009). These changes have emphasized increasing the planning period, using long-term or medium-term planning, developing formal mechanisms to set aside funds for preserving existing facilities, using special computer programs to increase automation of the process, increasing collaboration between agencies, and linking capital planning decisions to statewide performance goals and strategic plans.

Various state agencies involved in the development process including the Governor's Office, Legislative Budget Board, Higher Education Coordinating Boards, Facilities Commission, and other agencies. Through the input of 
information of these organizations, the Central Budget Office develops program guidelines, instructions and a formal application process for submitting capital project requests based on the legislative mandate. From a budgetary and capital planning standpoint, there are a number of state agencies that work together in varying degrees to coordinate the budgetary and capital reporting and approval process of state agencies. The central budget office coordinates the submission of capital projects, develops the report and determines the effect of the additional capital requests on the state's budget and debt capacity. The completed plan is then forwarded for use in their development of recommended appropriations to the Legislature. The Legislature makes the final decision on which projects will be funded. The central budget office (CBO) develops the Capital Projects Database (CPD), which is a statewide, web-based, secure application that will be used to capture agency capital project information. Table 1 demonstrates the organization of capital planning processes at the state level.

Table 1. Capital planning process organization

\begin{tabular}{|c|c|}
\hline State & Agencies and Committees responsible for preparing separate capital budget at the state level \\
\hline Alaska & Budget Office \\
\hline Arizona & $\begin{array}{l}\text { The Joint Legislative Budget Committee (JLBC); the Department of Administration (which } \\
\text { receives input from several other agencies), the Department of Transportation, and each of the } \\
\text { State Universities }\end{array}$ \\
\hline Arkansas & $\begin{array}{l}\text { The Arkansas Building Authority maintains agency long-range capital plans and reviews all } \\
\text { agency capital project requests. }\end{array}$ \\
\hline California & Governor's office. \\
\hline Colorado & Governor's Office of State Planning and Budgeting \\
\hline Connecticut & Treasurer's office \\
\hline Delaware & Division of Facilities Management \\
\hline Florida & The Department of Management Service, the State Board of Administration (for bonds) \\
\hline Georgia & General Assembly; Georgia State Financing and Investment Commission \\
\hline Hawaii & No, there is no separate capital budget at the state level \\
\hline Indiana & $\begin{array}{l}\text { The Office of Management and Budget, State Budget Agency, the Government Efficiency and } \\
\text { Financial Planning division, the Indiana Department of Administration, and the Indiana } \\
\text { Finance Authority }\end{array}$ \\
\hline Iowa & Department of Management \\
\hline Kansas & Kansas Division of the Budget \\
\hline Kentucky & Capital Planning Advisory Board \\
\hline Maine & $\begin{array}{l}\text { The Bureau of General Services; the Department of Administrative and Financial Services; } \\
\text { The Maine Governmental Facilities Authority; Governmental Facilities Authority. }\end{array}$ \\
\hline Maryland & $\begin{array}{l}\text { The State's Department of General Services, University System of Maryland, Department of } \\
\text { Public Safety, and Maryland Environmental Service, the State Treasurer's Office; the State's } \\
\text { Capital Debt Affordability Committee (CDAC); the Comptroller, the Secretary of Budget and } \\
\text { Management, the Secretary of Transportation, the Capital Budget Subcommittee of the Senate } \\
\text { Budget and Taxation Committee, and the chair of the Capital Budget Committee of the House } \\
\text { Committee on Appropriations. }\end{array}$ \\
\hline Massachusetts & Executive Office of Administration and Finance (EOAF) \\
\hline Minnesota & Minnesota Management and Budget (MMB) \\
\hline Mississippi & $\begin{array}{l}\text { The Bureau of Building, Grounds and Real Property Management (a division of the } \\
\text { Department of Finance \& Administration) }\end{array}$ \\
\hline Missouri & The Office of Administration \\
\hline
\end{tabular}




\begin{tabular}{|c|c|}
\hline State & Agencies and Committees responsible for preparing separate capital budget at the state level \\
\hline Montana & $\begin{array}{l}\text { Department of Architecture and Engineering; the Budget office; Department of Commerce and } \\
\text { Department of Natural Resources; Water Infrastructure projects. }\end{array}$ \\
\hline Nebraska & $\begin{array}{l}\text { The Department of Administrative Services - State Building Division, the State Budget } \\
\text { Division }\end{array}$ \\
\hline Nevada & Department of Administration, Governor's office; Treasurer's office \\
\hline New Jersey & $\begin{array}{l}\text { The Office of Management Budget (OMB); the Department of the Treasury; NJ Commission } \\
\text { Capital Budgeting and Planning }\end{array}$ \\
\hline New York & The Division of the Budget (DOB) \\
\hline North Carolina & Office of State Budget and Management \\
\hline North Dakota & The Building Authority \\
\hline Ohio & Office of Budgeting and Management; the Governor's office \\
\hline Oregon & $\begin{array}{l}\text { Capital Planning Advisory Committee (CPAC); the Budget and Management Division (BAM) } \\
\text { of the Department of Administrative Services. }\end{array}$ \\
\hline Pennsylvania & Office of the Budget \\
\hline Rhode Island & $\begin{array}{l}\text { The Budget Office as a part of the Department of Administration; the Capital Development } \\
\text { Planning and Oversight Committee, the Governor's office. }\end{array}$ \\
\hline South Carolina & $\mathrm{N} / \mathrm{A}$ \\
\hline South Dakota & Bureau of Finance \& Management \\
\hline Tennessee & Capital Projects Management \\
\hline Texas & $\begin{array}{l}\text { The Texas Bond Review Board (BRB); the Governor's Office of Budget, Planning \& Policy } \\
\text { (GOBPP), Texas Building and Procurement Commission Legislative Budget Board (LBB), } \\
\text { Texas Higher Education Coordinating Board (THECB),Texas Facilities Commission (TFC) }\end{array}$ \\
\hline Vermont & Agency of Administration and the Treasurer's Office review \\
\hline Virginia & Department of Planning and Budget (DPB) \\
\hline Washington & The Governor's office, Budget ; the Senate and House; the treasurer's office \\
\hline West Virginia & Budget Agency \\
\hline Wisconsin & Budget Agency \\
\hline
\end{tabular}

According to Ermasova (2013), Delaware, Indiana, Oregon, Texas, Utah, Washington, and Wisconsin have a State Board or Advisory Committee that submits its capital development recommendations and priorities to the Legislature for approval and prioritization. The Board or Advisory Committee makes recommendations on behalf of all state agencies, commissions, departments, and institutions. A budget director or budget officer is responsible for capacity generation, promotion of the flow of information within the Central Budget Agency and between agencies, synchronization of the key organizations, examination of mutual capabilities, and calibration of organizing structures to external needs.

Great examples linking capital planning decisions to statewide performance goals are provided by Delaware. The Delaware Code (Title 29, Chapter 91) creates the Cabinet Committee on State Planning Issues (CCSPI) to advise the governor on land-use planning, growth, and infrastructure-investment policy issues. To achieve this objective, the Cabinet Committee, through the Office of State Planning Coordination, developed the document the Strategies for State Policies and Spending to provide policy guidance for state activities and serve as a framework for the plans and actions of local governments. In this documents Strategies for State Policies and Spending (2010, p.6) were highlighted that "unlike most other states, Delaware provides many of the services and a great deal of infrastructure throughout the state. For example, the state maintains more than 90 percent of Delaware roads as compared to a national average of 20 percent. Comprehensive Plans are the best available tool for setting our path and determining where to make investments." The State Strategies are a large part of the state guidance for 
municipal planning and intergovernmental coordination between counties and municipalities. The Strategies and maps guide the development of county and municipal plans. They distinguish four different types of funding priorities of capital investments within each area. These types are distinguished by density; economic development, and long-term growth plan. Investment Level 1 Areas are often municipalities, towns, or urban/urbanizing places in counties. Investment Level 2 Areas can be composed of less developed areas within municipalities, rapidly growing areas in the counties that have or will have public water and wastewater services and utilities, smaller towns and rural villages that should grow consistently with their historic character, and suburban areas with public water, wastewater, and utility services. Investment Level 3 Areas generally fall into two categories: (1) lands that are in the long-term growth plans of counties or municipalities where development is not necessary to accommodate expected population growth during this five-year planning period (or longer; (2) lands that are adjacent to or intermingled with fast-growing areas within counties or municipalities. These lands are most often impacted by environmentally sensitive features, agricultural-preservation issues, or other infrastructure issues. Investment Level 4 Areas are rural in nature, and are where the bulk of the state's natural areas and agricultural industry is located. These areas contain agribusiness activities, farm complexes, and small settlements. In Investment Level 1 and 2 Areas state investments and policies should support and encourage a wide range of uses and densities, promote other transportation options, foster efficient use of existing public and private investments, and enhance community identity and integrity. Levels 1-3, are the areas that state policies will support growth and economic development activities with Levels 1 and 2 being the primary focus. Level 4 is where state policies will support agriculture and open-space activities including the promotion of agriculture industry support activities. The state infrastructure investments maybe appropriate where state and local governments agree that such actions are necessary to address unforeseen circumstances involving public health, safety, or welfare.

Other example examples linking capital planning decisions to statewide performance goals are provided by California. The Governor is required to annually submit a Five-Year Infrastructure Plan in conjunction with the Governor's Budget. All Five-Year Infrastructure Plans must consider the state planning priorities, as required by Government Code section 65041.1, including, but not limited to the following:

- Promote infill development by rehabilitating existing infrastructure.

- Protect environmental and agricultural resources by protecting and preserving the state's most valuable natural resources.

- Encourage efficient development patterns by ensuring that infrastructure associated with development, other than infill, support efficient use of land and is appropriately planned for growth.

Georgia's State government has weathered the economic downturn by focusing on its core services and finding more efficient ways of capital financing. State's Program budgeting incorporates strategic planning and performance measures in the annual budget development cycle. Revenue growth for FY 2013 will likely be modest compared to growth in key state services such as education, healthcare, and public safety. In conjunction with developing the FY 2013 budget requests, agencies should prioritize programs/sub-programs and consider how they support not only the statutory responsibilities of the agency but also the initiatives within the agency strategic plan. According to Georgia Governor's Office of Planning and Budget Amended FY 2012 and FY 2013 Budget Instructions (2012), "In order to ensure that funded priority major capital facility projects advance expeditiously from design to completion, agencies are instructed to develop their funding requests as follows: (1) Funding of major facility projects of $\$ 10$ million or more total project cost; (2) Initial FY of Funding - Request funding for Design [If recommended for Design, 5 -year bonds will be used as design is relatively short-term, limited-life, and does not result in a physical asset] ; (3) Next FY - Request funding for Construction [If recommended, 20-year bonds will be used] ; (4) Third or Fourth FY - Request funding for Equipment and Furnishings based on scheduled need [If recommended, 5-year bonds will be used] ; (5) Funding of major facility projects of less than $\$ 10$ million total project cost."

Capital financing sources fall into three broad categories: pay-as-you-go financing, debt financing and mixed system financing. Pay-as-you-go sources are comparable to equity financing of capital needs in the private sector. Such financing is raised through stock offerings or other contributions of capital by owners, partners, or stockholders. Pay-as-you-go financing for state government comes from taxes and other revenues or capital that are directly contributed by the taxpayers or citizens. Pay-as-you-go or equity finance stands in contrast to debt financing, where the state government or private firm borrows capital and incurs debt to finance capital projects and acquisitions. The following pay-as-you-use resources are typically available for agencies to draw upon to 
finance capital projects at the state level: (1) use of treasury loans; (2) revenue bonds; (3) general obligations; (4) bond anticipation notes; (5) interfund borrowing; (6) revenue notes; and (7) tax exempt commercial paper.

Many states impose user fees on intended beneficiaries of capital projects in order to help service the debt issued to finance them. In many states, significant amounts of capital expenditures, such as those for transportation (mainly highways), special authorities (e.g., university systems, hospitals, or toll roads), or aid to localities are not included in the state capital budget, or perhaps even in the state budget itself more generally.

\section{Conclusions}

Many states viewed the economic downturn as an opportunity to move forward with capital projects to boost the economy and to take advantage of lower construction costs. This research is consistent with Premchhand's proposition (2006, p.27) that "the nature and dimensions of the fiscal stress was such that it became abundantly clear that the traditional methods of nip and tuck, or a cut here or there in the sectoral allocations, would not serve the purpose." Pure cutback management can lead to ad hoc and non-purposeful strategies. Cutback management must be combined with improvements in the capital budgeting and financing processes. This study proves that during economic downturns, many states increase the duration of their capital plan, improve medium-term capital expenditure planning; highlight the prioritization and selection process, place an emphasis on improved governance through greater fiscal transparency and an enhanced financial and program accountability framework, improve budget making through a special decision-support computer system, develop a comprehensive analysis of capital budget needs, improve coordination with the operating budget, emphasize planning and execution of preventive maintenance, and improve cash-monitoring controls.

By focusing on state government's policies and capital budgeting practices, this analysis is not only an evaluation of the individual states' capital budgeting processes, but it is also an analysis of tendencies in capital budgeting processes across all states. This research will expend knowledge of capital budgeting for practicing planners, developers, budget analytics, debt managers, and policy makers in the areas of regional collaboration, capital planning, and capital budgeting. Finally, the findings from this research will contribute to the theories that economic decline can be trigger for improvements in capital budgeting in the budget agencies of governments at the state level.

\section{References}

Ammar, A., Duncombe, R., \& Wright, A. (2001). Evaluating Capital Management: A New Approach. Public Budgeting \& Finance, 2(1), 47-69. http://dx.doi.org/10.1111/0275-1100.00058

Boex, J. L., Martinez-Vazquez, J., \& McNab, R. M. (2000). Multi-Year Budgeting: A Review of International Practices and Lessons for Developing and Transitional Economies. Public Budgeting \& Finance, 6(3), 91-112. http://dx.doi.org/10.1111/0275-1100.00013

Bozeman, B., \& Straussman, J. (1982). Shrinking budgets and the shrinkage of budget theory. Public Administration Review, 42(6), 514-519. http://dx.doi.org/10.2307/976120

Bozeman, J. (1984). The Capital Budget: History and Future Directions. Public Budgeting \& Finance, 4(2), 18-30. http://dx.doi.org/10.1111/1540-5850.00647

California Department of Finance's (Finance). (2011). Five-Year Infrastructure Plans. Retrieved from http://www.dof.ca.gov/fisa/bag/bagtoc.htm

Center of Budget Policy and Priorities. (2012). Out of Balance: Cuts in Services Have Been States' Primary Response to Budget Gaps, Harming the Nation's Economy. Retrieved from http://www.cbpp.org/cms/index.cfm?fa=view\&id=3747

Damanpour, F., \& Evan, W. M. (1984). Organizational Innovation and Performance: The Problem of "Organizational Lag". Administrative Science Quarterly, 29(3), 392-409. http://dx.doi.org/10.2307/2393031

Delaware Planning Department. (2010). Strategies for State Policies and Spending. Retrieved from http://stateplanning.delaware.gov/strategies/2010_state_strategies.pdf

Dorotinsky, W. (2008). Capital Budgeting and Public Financial Management-Part I \& II. IMF's PFM Blog. Retrieved from http://blog-pfm.imf.org

Doss, B. (1987). The Use of Capital Budgeting Procedures in U.S. Cities. Public Budgeting \& Finance, 57-69. http://dx.doi.org/10.1111/1540-5850.d01-232 
Dougherty, M., \& Klase, K. (2009). Fiscal retrenchment in state budgeting: Revisiting cutback management in a new era. International Journal of Public Administration, 32(7), 593-619. http://dx.doi.org/10.1080/01900690902952156

Downs, A. (1967). Inside Bureaucracy. New York: Little, Brown.

Downs, G., \& Rocke, M. D. (1984). Theories of budgetary decision-making and revenue decline. Policy Sciences, 16(1), 329-347. http://dx.doi.org/10.1007/BF00135953

Ermasova, N. (2013). Capital Budgeting in the States After the Great Recession. State and Local Government Review, 45(2), 119-130. http://dx.doi.org/10.1177/0160323X13487079

Georgia's Governor's Office of Planning and Budget. (2012). Amended FY 2012 and FY 2013 Budget Instructions. Retrieved from http://opb.georgia.gov/governors-budget-reports

Goldman, S. (1987). AABPA Symposium: Capital Budgets-Expanded Use in Federal Sector. Public Budgeting \& Finance, 7, 4-10. http://dx.doi.org/10.1111/1540-5850.00748

Halachmi, A., \& Sekwat, A. (1997). Strategic Capital Budgeting and Planning: Prospects at the County Level. Public Budgeting and Financial Management, 1, 578-596

Heintz, P., Pollin, R., \& Garrett-Peltier, A. (2009). How Infrastructure Investments Support the U.S. Economy: Employment, Productivity and Growth. Political Economy Research Institute. Retrieved from http://www.americanmanufacturing.org/wordpress/wp-content/uploads/2009/01/peri_aam_finaljan16_new. pdf

Hillhouse, A., \& Howard, K. (1963). State Capital Budgeting. Chicago, IL: Council of State Governments.

Hou, Y. (2006). Budgeting for Fiscal Stability over the Business Cycle: A Countercyclical Fiscal Policy and the Multiyear Perspective on Budgeting. Public Administration Review, 66(5), 32-41. http://dx.doi.org/10.1111/j.1540-6210.2006.00638.x

Howard, A. (2006). Public Financial Management. New York: Business \& Economics.

Hoyle, R. (1978). Capital Budgeting Models and Planning: An Evolutionary Process. Managerial Planning, 27, 14-31.

Hush, L., \& Peroff, K. (1988). The Variety of State Capital Budgets. Public Budgeting and Finance, 3, 67-79. http://dx.doi.org/10.1111/1540-5850.00783

Hyde, A. (1992). The Development of Budgeting and Budget Theory: The Threads of Budget Reform. In A. C.Hyde (Ed.), Government Budgeting: Theory, Process, Politics (pp. 1-6). Pacific Grove, CA: Brooks/Cole Publishing.

Hyde, A. (2002). Government Budgeting. Theory, Process, and Politics (3rd ed.). Washington DC: The Brookings Institution Center for Public Policy Education.

Indiana Budget Office. (2011). Capital Budget Development Process for FY 2012 and FY 2013. Retrieved from http://www.in.gov/sba/files/7.29.10.Capital_Budget_Instructions.pdf

Jacobs, D. (2008). A Review of Capital Budgeting Practices. IMF Working Paper of Fiscal Affairs Department. Retrieved from http://blog-pfm.imf.org/pfmblog/files/a_review_of_capital_budgeting_practices1.pdf

Jacobs, D. (2009). PFM Technical Guidance Note NO. 81 Capital Expenditures and the Budget. Retrieved from http://blog-pfm.imf.org/files/capital-expenditures-and-the-budget.pdf

Levine, C. (1978). Organizational decline and cutback management. Public Administration Review, 38(4), 316-325. http://dx.doi.org/10.2307/975813

Levine, C., Rubin, I., \& Wolohojian, G. (1981). The politics of retrenchment: How local governments manage fiscal stress. Beverly Hills, Calif.: Sage Publications.

Mayer, R. (1978). Capital Expenditure Analysis. Prospect Heights, Illinois: Waveland Press.

McClain, J. (1966). Capital Budgeting in Selected States. Lexington, Ky.: Bureau of Business Research, College of Commerce, University of Kentucky.

McNichol, E., Oliff, P., \& Johnson, N. (2011). States Continue to Feel Recession's Impact. Center on Budget and Policy Priorities. Retrieved from http://www.cbpp.org/files/9-8-08sfp.pdf

Meyer, A. (1982). Adapting to environmental jolts. Administrative Science Quarterly, 27, 515-537. http://dx.doi.org/10.2307/2392528 
Meyer, A., \& Goes, J. (1988). Organizational Assimilations and Innovation: A Multilevel Contextual Analysis. Academy of Management Journal, 31, 897-923. http://dx.doi.org/10.2307/256344

Meyer, A., Brooks, G., \& Goes J. (1990). Environmental jolts and industry revolutions: organizational responses to discontinuous change. Strategic Management Journal, 11, 93-110.

Meyer, J. (1980). The World Polity and the Authority of the Nation-State. In A. Bergesen (Ed.), Studies of the Modern World-System (pp.109-137). New York: Academic Press.

Meyer, J. (1994). Rationalized Environments. In R. Scott \& J. Myer, Institutional Environments and Organizations (pp. 28-54). Newbury Park, California: Sage.

Meyer, J. W., \& Rowan, B. (1977). Institutionalized Organizations: Formal Structure as Myth and Ceremony. American Journal of Sociology, 83, 340-363. http://dx.doi.org/10.1086/226550

Meyer, M. (1979). Change in Public Bureaucracies. Cambridge: Cambridge University Press. http://dx.doi.org/10.1017/CBO9780511983771

Mikesell, J. (2007). Changing state fiscal capacity and tax effort in an era of devolving government, 1981-2003. The Journal of Federalism, 37(4), 532-550. http://dx.doi.org/10.1093/publius/pjm016

Mikesell, J. (2007). Fiscal Administration (7th ed.). Wadsworth: Cengage Learning.

Mikesell, J. (2011). Fiscal Administration (8th ed.). Wadsworth: Cengage Learning.

Mintz, J., \& Preston, R. (1993). Capital Budgeting in the Public Sector. Kingston,Canada: John Deutsch Institute for the Study of Economic Policy.

Mintzberg, H. (1990). The design school: reconsidering the basic premises of strategic management. Strategic Management Journal, 11(3), 171-195. http://dx.doi.org/10.1002/smj.4250110302

Mintzberg, H., \& Waters, J. (1985). Of strategies, deliberate and emergent. Strategic Management Journal, 6(3), 253-259. http://dx.doi.org/10.1002/smj.4250060306

Moak, L., \& Gordon, K. (1965). Budgeting for Smaller Governmental Units. Chicago: Municipal Finance Officers Association.

Moak, L., \& Hillhouse, A. (1975). Concepts and practices in local government finance. Chicago: Municipal Finance Officers Association of the United States and Canada.

National Association of State Budget Officers. (1999). Budget Process in the States. Retrieved from http://www.nasbo.org/publications.php

National Association of State Budget Officers. (2000). Capital Budgeting in the States. Path to Success: A Comparative Analysis of Capital Budgeting Practices in the States. Retrieved from http://www.nasbo.org/publications.php

National Association of State Budget Officers. (2002). Budget Process in the States. Retrieved from http://www.nasbo.org/publications.php

National Association of State Budget Officers. (2009). Budget Process in the States. Retrieved from http://www.nasbo.org/publications.php

National Association of State Budget Officers. (2010). State Expenditure Report. Retrieved from $\mathrm{http}: / /$ www.nasbo.org/publications.php

Premchand, A. (1983). Government Budgeting and Expenditure Controls-Theory and Practice. Washington D.C.: International Monetary Fund.

Premchand, A. (1993). Public Expenditure and Management: Selected Themes and Issues. Washington D.C.: International Monetary Fund.

Premchand, A. (2007). Capital Budgets: Theory and Practice/ Budgeting and Budgetary Institution. In A. Shah (Ed.), 91-113. Washington D.C.: The International Bank for Reconstruction and Development.

President's Clinton Commission. (1999). Report of the President's Commission to study capital budgeting. Retrieved from http://clinton3.nara.gov/pcscb/report.html\#trends

Schick, A. (2008). The road to PPB: The stages of budget reform. in the book Public Budgeting. Policy, Process, and Politics. In I. Rubin (Ed.), Public Budgeting. Policy, Process, and Politics (pp. 27-44). New York, NY: Economics and Business. 
Srithongrung, A. (2008). Impacts of State Capital Management Programs on State Economic Performance. Public Budgeting \& Finance, 28(3), 83-107. http://dx.doi.org/10.1111/j.1540-5850.2008.00912.x

Wildavsky, A. (1964). The politics of the budgetary process. Boston: Little, Brown.

Wildavsky, A. (1979). Speaking Truth to Power: the art and craft of policy analysis. Boston, Little Brown.

\section{Copyrights}

Copyright for this article is retained by the author(s), with first publication rights granted to the journal.

This is an open-access article distributed under the terms and conditions of the Creative Commons Attribution license (http://creativecommons.org/licenses/by/3.0/). 